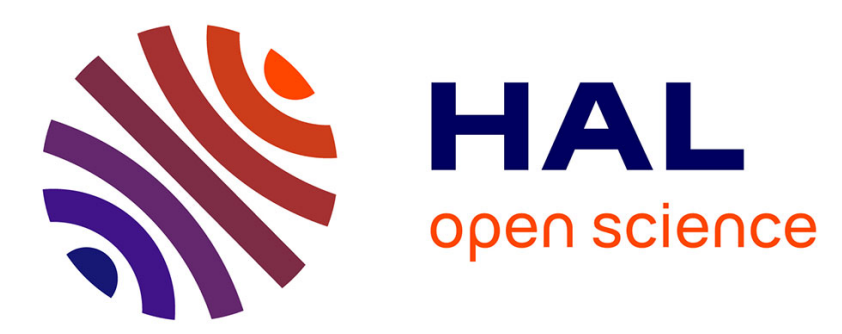

\title{
Development and use of new sensitive molecular tools for diagnosis and detection of [i]Melampsora[/i] rusts on cultivated poplar
}

\author{
Claude Husson, Renaud Ioos, Axelle Andrieux, Pascal Frey
}

\section{To cite this version:}

Claude Husson, Renaud Ioos, Axelle Andrieux, Pascal Frey. Development and use of new sensitive molecular tools for diagnosis and detection of [i]Melampsora[/i] rusts on cultivated poplar. Forest Pathology, 2013, 43 (1), pp.1-11. 10.1111/efp.12007 . hal-01136979v2

\section{HAL Id: hal-01136979 \\ https://hal.science/hal-01136979v2}

Submitted on 15 Dec 2015

HAL is a multi-disciplinary open access archive for the deposit and dissemination of scientific research documents, whether they are published or not. The documents may come from teaching and research institutions in France or abroad, or from public or private research centers.
L'archive ouverte pluridisciplinaire HAL, est destinée au dépôt et à la diffusion de documents scientifiques de niveau recherche, publiés ou non, émanant des établissements d'enseignement et de recherche français ou étrangers, des laboratoires publics ou privés. 
For. Path. 43 (2013) 1-11

(C) 2012 Blackwell Verlag GmbH

doi: 10.1111/efp.12007

\title{
Development and use of new sensitive molecular tools for diagnosis and detection of Melampsora rusts on cultivated poplar
}

\author{
By C. Husson ${ }^{1,3}$, R. Ioos $^{2}$, A. Andrieux ${ }^{1}$ and P. Frey ${ }^{1}$ \\ ${ }^{1}$ INRA, UMR1136 INRA Université de Lorraine “Interactions Arbres/Micro-organismes”, IFR110 EFABA, Centre INRA de Nancy, 54280, \\ Champenoux, France; ${ }^{2}$ Anses, Laboratoire de la Santé des Végétaux, Unité de Mycologie, IFR110 EFABA, Domaine de Pixérécourt, F-54220, \\ Malzéville, France; ${ }^{3}$ E-mail: claude.husson@nancy.inra.fr (for correspondence)
}

\begin{abstract}
Summary
Poplar rusts due to Melampsora larici-populina (Mlp), M. allii-populina (Map) and M. medusae f. sp. deltoidae (Mmd) are the most serious disease in Europe on cultivated poplars, that is, Populus $\times$ euramericana and $P . \times$ interamericana hybrids. These pathogenic species can be identified by the observation of morphological characteristics of urediniospores but this method is not appropriate for high-throughput analysis and cannot be used on other spore stages, such as aeciospores or teliospores, that are morphologically similar. The aim of this study was to develop a rapid and sensitive molecular method based on PCR amplification that was able to specifically detect these species on various hosts for routine analysis. Three primer pairs ITS-MLP-F/ITS-MLP-R, ITS-MAP-F/ITS-MAP-R and ITS-MMD-F/ITS-MMD-R were designed within the internal transcribed spacer (ITS) sequences of ribosomal DNA to target Mlp, Map and Mmd, respectively, and their specificity were confirmed on a wide range of isolates and species. ITS-MLP-F/ITS-MLP-R and ITS-MAP-F/ITS-MAP-R primers proved to be highly specific to Mlp and Map, respectively, whereas ITS-MMD-F/ITS-MMD-R cross-reacted with DNA from M. larici-tremulae and M. pinitorqua. However, these species are not pathogenic on cultivated poplars that all belong to sections Aigeiros and Tacamahaca of the genus Populus. Specific Mmd primers proved to be very sensitive as a positive signal could be obtained with DNA extracts from 6 target urediniospores mixed with 800000 urediniospores of Mlp. An internal amplification control (IAC) was included to discriminate false negative results due to the potential presence of inhibitory compounds in DNA extracts. ITS-MMD-F/ITS-MMD-R primers are therefore efficient for the detection of the quarantine pathogen Mmd on samples collected on poplar or larch and are fit for use in official tests. This new PCR assay has been used in routine for ten years, and $M m d$ has hitherto never been detected in commercial poplar nurseries in France.
\end{abstract}

\section{Introduction}

The genus Populus is divided in six sections and includes 29 species (Eckenwalder 1996). Most of the cultivated poplars belong to sections Aigeiros (Populus deltoides (Bartr.) Marsh. and Populus nigra L.) and Tacamahaca (P. trichocarpa Torr. \& Gray ex Hook.), and their hybrids, that is, $P . \times$ euramericana (Dode) Guinier. and $P . \times$ interamericana Brockh. In Europe, the acreage of poplar plantations is much lower than other forest trees, but as hybrid poplars are fast-growing trees selected for their vigour, annual wood harvest is close to other widespread broadleaved trees, such as oak or beech. For example, in France, 240000 ha of widely spaced poplar cultivation (1.6\% of the total forest area) produce approximately 1.3 million $\mathrm{m}^{3}$ of wood per year, that is, approximately $25 \%$ of broadleaved wood production (AFOCEL 2009). Poplar wood is mainly used for veneer and plywood (Pinon et al. 2006). Another recent interest of poplar cultivation is the cultivation of short rotation coppice (SRC) for the production of wood as a renewable energy source (Vande Walle et al. 2007; Paris et al. 2011). Moreover, research about poplar biomass conversion to bioethanol is in progress (Pu et al. 2011; Swana et al. 2011).

In widely spaced poplar cultivation, trees are cultivated as monoclonal stands covering several hectares, with a small number of cultivars used in each region. In France, two-thirds of the stands involve no more than three cultivars (Pinon et al. 2006). This monoculture practice is favourable to the development of epidemics of fungi, bacteria and insects (Royle and Ostry 1995; Miot et al. 1999).

Among fungal diseases, foliar rust due to the basidiomycetes Melampsora spp. is the most serious disease on cultivated poplar worldwide. M. larici-populina Kleb. (Mlp) causes severe economic losses in Europe, mainly on P. $\times$ euramericana and $P . \times$ interamericana hybrids, in particular since the breakdown of several major resistance genes (Pinon and Frey 2005; Pinon et al. 2011). Symptoms are premature defoliation, growth decrease and delayed bud burst the year following infection. On the widely planted cultivar 'Beaupré', biomass losses were estimated to be $20-30 \%$ in the first year of infection and 50-60\% during the following years (Gastine et al. 2003). Many young infected trees can be killed after secondary infection due to Discosporium populeum Sacc. (Pinon et al. 2006).

Two others species, that is, Melampsora allii-populina Kleb. (Map) and M. medusae Thüm. f. sp. deltoidae Shain (Mmd) can infect cultivated poplars in Europe but cause less economic impact (Frey et al. 2005). Map is more frequent in southern and western France (Pinon 1991; Desprez-Loustau et al. 2007), but recent studies on the effects of climate change have shown that its geographical distribution could be modified during the next decades due to an increase in summer temperature, leading to a higher prevalence in northern France (Desprez-Loustau et al. 2007). This species could therefore jeopardize the cultivated poplars in the future, especially the cultivation of biomass poplars in SRC. The North American species Mmd, probably introduced in Europe at the beginning of the 20th century, is very rare and is restricted to south-western France, Spain and Portugal (Pinon 1986, 1991). Up to now, no damage on poplar caused by this species is reported in 
Europe, whereas it causes important economic losses in the USA (Widin and Schipper 1981; Newcombe et al. 1994; Bourassa et al. 2007), Australia (Walker et al. 1974) and New Zealand (Wilkinson and Spiers 1976). In Europe, Mmd is listed as a quarantine pest for EPPO (OEPP/EPPO 1982). In this respect, the trade of poplar plants in European Union countries requires a phytosanitary passport, which states the absence of $M m d$ in the cultivation area. Official inspections of the nurseries are carried out on a yearly basis by the national plant protection authorities, and if necessary, samples of symptomatic leaves may be sent for analysis in official quarantine laboratories for the identification of the rust species.

Six others species of Melampsora, namely M. larici-tremulae Kleb., M. rostrupii G. H. Wagner, M. pinitorqua Rostr., M. magnusiana G. H. Wagner, M. pulcherrima Maire and M. aecidioides (DC.) J. Schröt, are present on Populus sp. in Europe (Pinon 1973; Feau et al. 2009; Vialle et al. 2011). These species are only pathogenic on poplars belonging to section Populus (P. alba L. and P. tremula L.) and theirs hybrids (P. canescens (Ait.) Sm.), which are not much used in poplar cultivation in Europe (Pinon 1973; Vialle et al. 2011).

The morphological identification of Mlp, Map and Mmd based on the observation of urediniospores and paraphyses is straightforward and only requires a light microscope (Pinon 1973; Vialle et al. 2011). However, this method is time-consuming and can be only performed at the uredinial stage on poplar. Therefore, the development of species-specific molecular tools based on DNA amplification by polymerase chain reaction (PCR) would be of great interest for highthroughput analysis of samples collected on both the telial hosts (poplars) and the aecial hosts (Larix sp. for Mlp and Mmd and Allium sp., Arum sp. or Muscari sp. for Map).

Species-specific primer pairs designed from random amplified polymorphic DNA (RAPD) fragments were developed for identifying and characterizing Mmd by single-strand conformational polymorphism (SSCP) (Bourassa et al. 2005), but this technique is not straightforward for diagnosis or detection. In addition, ITS-based real-time PCR assays using SYBR Green dye have been developed to quantify Mlp or Mmd DNA in planta (Boyle et al. 2005; Hacquard et al. 2011). These PCR assays were successfully used to monitor the dynamics of the fungal colonization in infected leaves, but their specificity was not validated on a wide range of rust fungi, and therefore, they cannot be used as reliable identification tools.

The aim of this study was to design new species-specific primer pairs to (i) develop a rapid and efficient method based on PCR amplification for identifying all rust species pathogenic on cultivated poplars for routine analysis, (ii) distinguish these species regardless of their biological stage or telial/aecial host plant and (iii) detect the quarantine pathogen $M m d$ at low prevalence when mixed with an excess of another species. The ITS region of nuclear ribosomal DNA has been shown to be a suitable target for molecular detection assay development in rust fungi (Chung et al. 2008; Pedley 2009). Furthermore, it was proved to be the most efficient DNA barcode for fungi (Schoch et al. 2012) and particularly for poplar rust species delineation (Feau et al. 2009) and was therefore chosen in our study for designing primer pairs.

\section{Materials and Methods}

\subsection{Sample collection}

A total of 88 isolates of Mlp, Map and Mmd and 21 isolates of Melampsora species pathogenic on section Populus (M. laricitremulae, M. rostrupii, M. pinitorqua, M. magnusiana, M. aecidioides, M. pulcherrima) were collected from a wide range of host plants (poplars and aecial hosts) in numerous geographical locations (Table 1).

The production of urediniospores was carried out using the method originally described by Gérard et al. (2006) with slight modifications. Spores from single uredinia or aecia from infected plant tissue were transferred onto a leaf disc of P. $\times$ euramericana 'Robusta' for Mlp, Map and Mmd isolates or P. tremula $\times$ P. alba '717-1B4' for M. larici-tremulae, $M$. rostrupii and $M$. pinitorqua isolates. Both poplar clones were grown from cuttings in 5-litre pots containing sand and peat mixture, in a rust-free glasshouse. A $20-\mu$ l droplet of water agar $\left(0.1 \mathrm{~g} \mathrm{l}^{-1}\right)$ was deposited onto each selected uredinium or aecium with a micropipette, and spores were dispersed within the droplet with the micropipette. The resulting spore suspension was applied as $1-\mu \mathrm{l}$ droplets on the abaxial surface of 12-mm-diameter leaf discs of cultivars 'Robusta' or '717-1B4'. Leaf discs were incubated floating on deionized water in 24-well polystyrene cell culture plates, with the abaxial surface above, at $19 \pm 1^{\circ} \mathrm{C}$, and under continuous fluorescent light. After an 8- to 10-day incubation period, the sporulating discs were removed from the plates and the resulting urediniospores were suspended in $50 \mathrm{ml}$ of water agar $\left(0.1 \mathrm{~g} \mathrm{l}^{-1}\right)$. Leaves of cultivars 'Robusta' or '717-1B4' were inoculated by spraying with this spore suspension. After a 10- to 12-day incubation period, the leaves were dried at room temperature for $24 \mathrm{~h}$. Urediniospores were then harvested by tapping on the adaxial surface over aluminium paper. Urediniospore samples were kept refrigerated at $+1^{\circ} \mathrm{C}$ in a 2 -ml glass tube when used the following days or in liquid nitrogen in a plastic tube for prolonged storage.

\subsection{Estimation of the number of urediniospores per $\mathrm{mg}$}

Three milligrams of Mlp or Mmd urediniospores was added to $100 \mathrm{ml}$ water agar $\left(0.1 \mathrm{~g} \mathrm{l}^{-1}\right)$. The suspension was shaken for 10 min with a rotary shaker (IKA Vibrax VXR; Janke \& Kunkel, Staufen, Germany) at 1000 rpm. The number of spores per $\mathrm{ml}$ was determined using a haemocytometer, with ten replicates per species.

\subsection{Mixture of Melampsora species}

Serial dilutions of urediniospores were performed to determine the detection threshold for $M m d$. One milligram of $M m d$ urediniospores was mixed with $9 \mathrm{mg}$ of Mlp urediniospores into a 2-ml round-bottom Eppendorf tube and vortexed for 


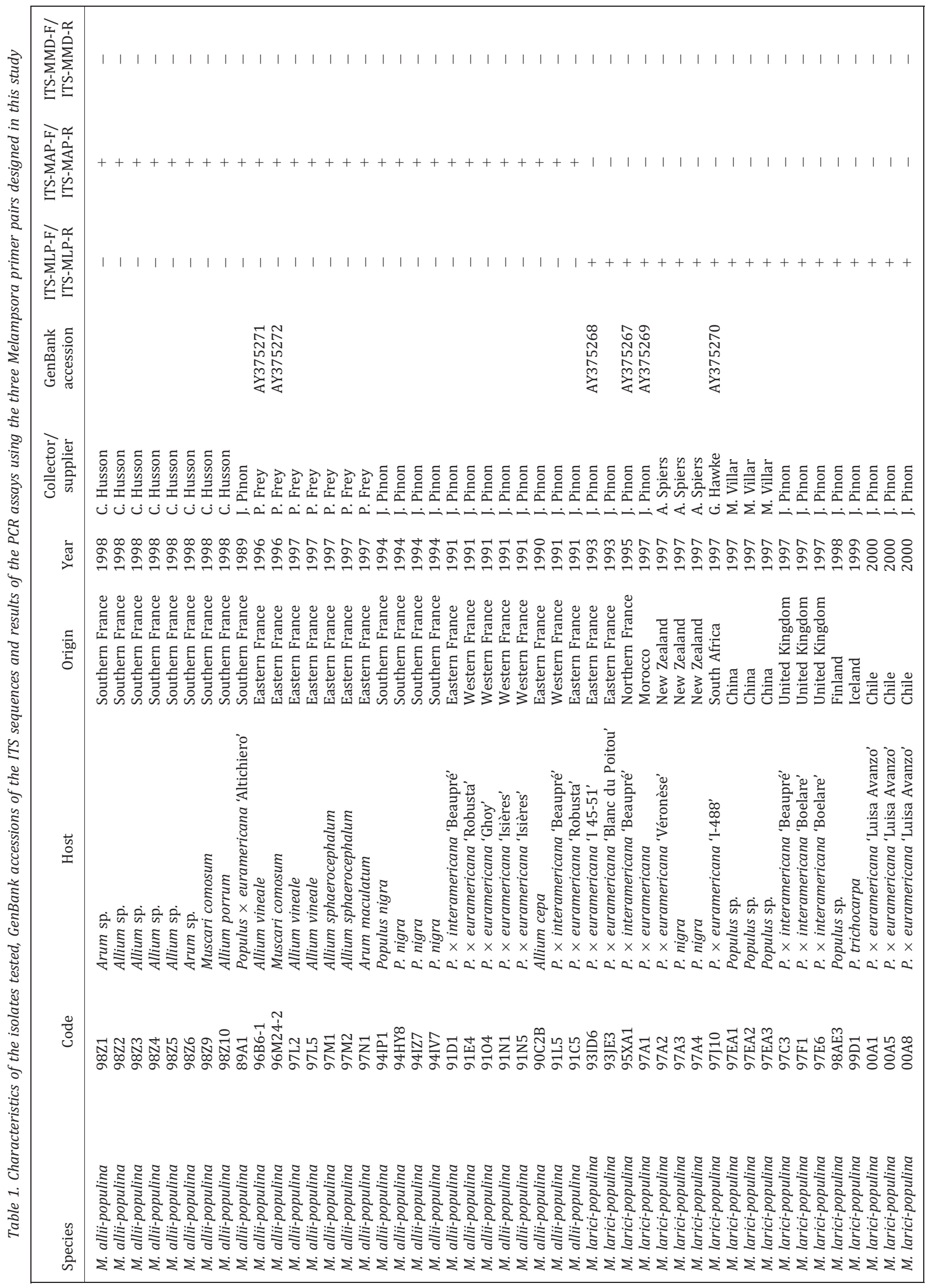




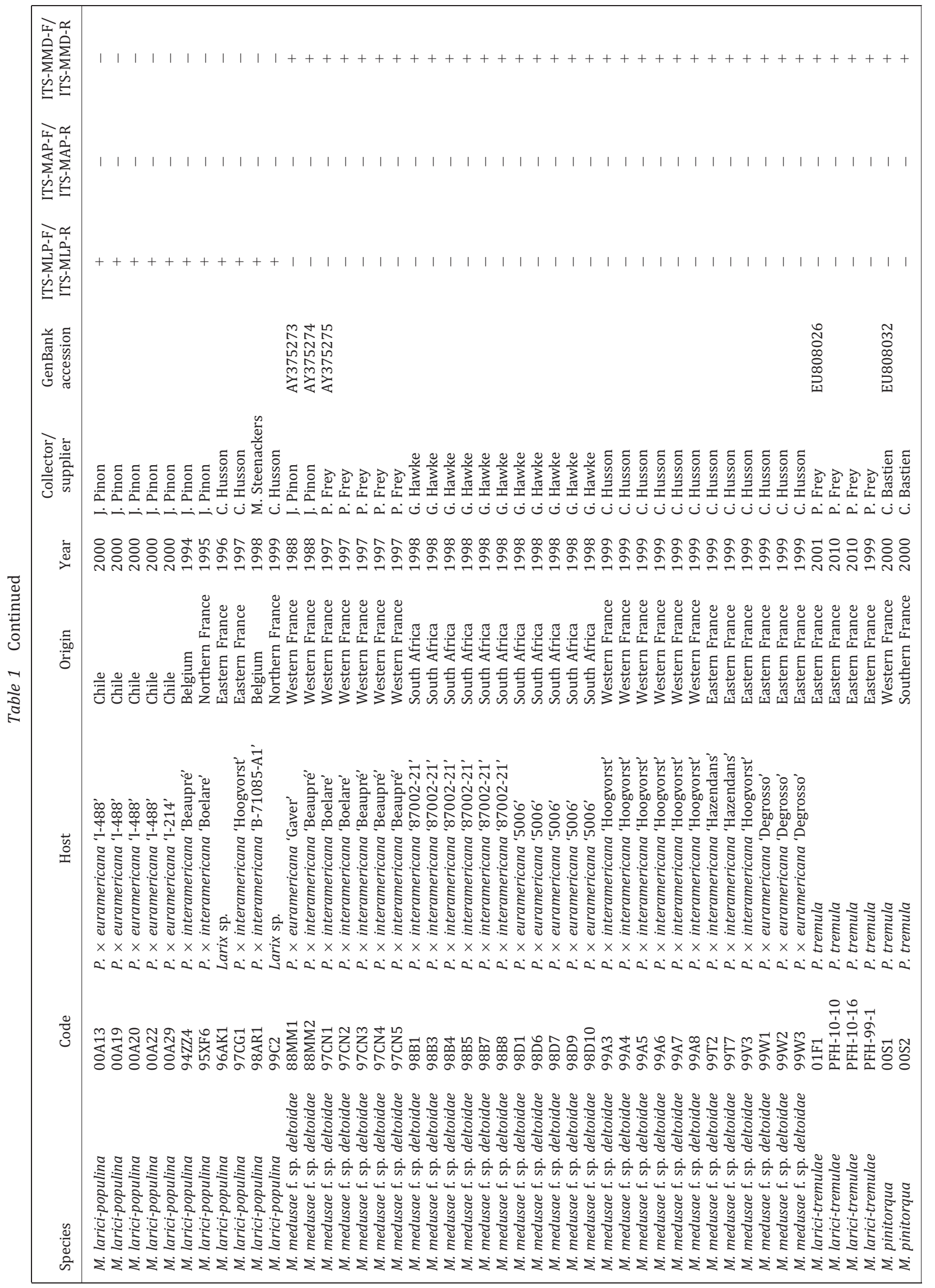




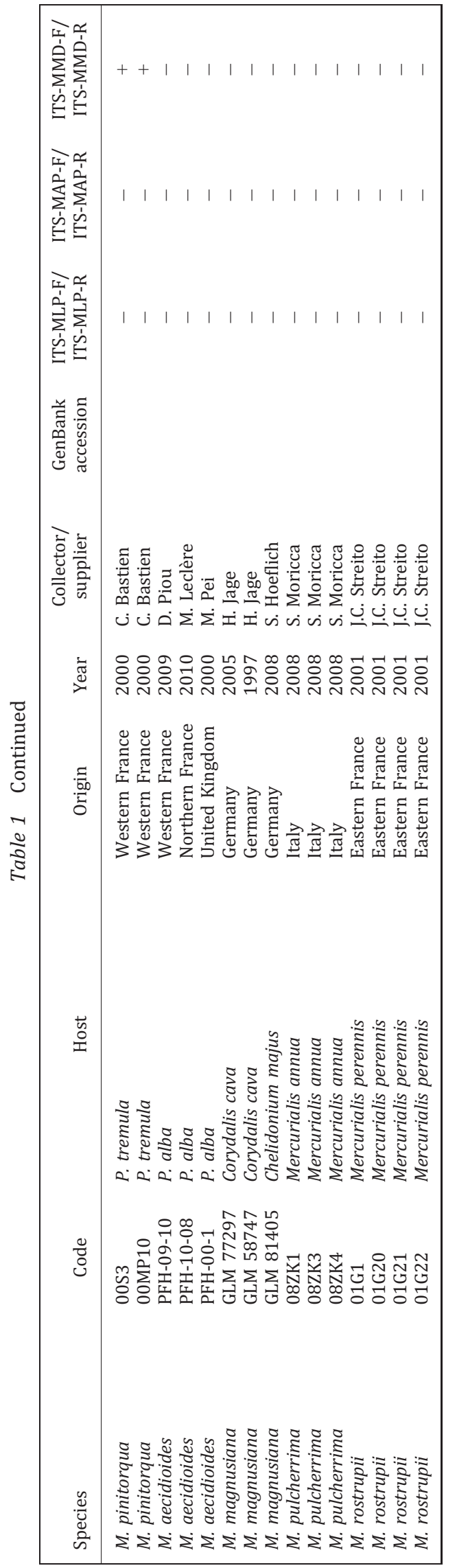


10 min. One milligram of this mixture was then collected and mixed again in another tube with 9 mg of Mlp urediniospores. This process was repeated four times to prepare a 10-fold dilution series, and finally, the last mixture was a 2-fold dilution. The number of Mmd urediniospores, readily distinguishable from Mlp urediniospores on the basis of their ornamentation (position of echinulations), was assessed for the two-first dilutions by microscopy.

\subsection{DNA extraction}

Two milligrams of urediniospores from pure mono-uredinial isolates or from mixture of two species was ground for 5 min with ten 2-mm-diameter glass beads and $100 \mu \mathrm{l}$ of extraction buffer at $5000 \mathrm{rpm}$ by using a shaker (Ika Vibrax VXR) (Pei et al. 1997). The extraction buffer contained $100 \mathrm{~mm}$ Tris (pH 9.0), 20 mм EDTA (pH 8.0), 1.4 mm NaCl, 2\% CTAB and $0.2 \%$ mercaptoethanol. Total DNA was extracted using the protocol described by Henrion et al. (1994). DNA was finally eluted in $50 \mu \mathrm{l}$ TE Buffer (10 mm Tris- $\mathrm{HCl}, \mathrm{pH}$ 8.0, $1 \mathrm{~mm}$ EDTA, pH 8.0) and stored at $-20^{\circ} \mathrm{C}$ until used for PCR tests. The DNA concentration was measured by Hoechst fluorometry (Charcosset and Gardes 1999). In addition, DNA was extracted from approximately $20 \mathrm{mg}$ of poplar leaf ('Robusta') or larch (Larix decidua) needles following the protocol described above. DNA extracts were diluted 10 or 100 -fold before PCR amplifications.

\subsection{Amplification of ITS sequences, cloning, DNA sequencing and primer design}

The ITS regions of four isolates of Mlp (95XA1, 93ID6, 97A1 and 97J10), two isolates of M. allii-populina (96B6-1 and 96M21-1) and three isolates of Mmd (88MM1, 88MM2 and 97CN1) were amplified with universal primers ITS1 and ITS4 (White et al. 1990). PCR amplification was carried out in $20-\mu$ final reaction volumes containing $1 x$ Taq DNA polymerase buffer (Sigma-Aldrich, Lyon, France), $1.5 \mathrm{~mm} \mathrm{MgCl2,} 0.2 \mu \mathrm{m}$ of each primer, $200 \mu \mathrm{m} \mathrm{dNTP,} 0.5$ unit of Taq DNA polymerase (Sigma-Aldrich), $2 \mu \mathrm{l}$ of template DNA (0.2-2 ng), and ultrapure water was added to $20 \mu \mathrm{l}$. PCRs were performed by using a PTC-200 Peltier Thermal Cycler (MJ Research, Bio-Rad, Marnes-la-Coquette, France) and included an initial denaturation at $94^{\circ} \mathrm{C}$ for $3 \mathrm{~min}$ followed by 30 cycles at $94^{\circ} \mathrm{C}$ for $30 \mathrm{~s}, 55^{\circ} \mathrm{C}$ for $30 \mathrm{~s}, 72^{\circ} \mathrm{C}$ for $90 \mathrm{~s}$ and a final extension at $72^{\circ} \mathrm{C}$ for $10 \mathrm{~min}$. As rust fungi are dikaryotic, to avoid sequencing errors due to heterozygous positions, the amplicons were cloned for each isolate, using the $\mathrm{pCR}^{\circledR}$ 4-TOPO ${ }^{\circledR}$-TA cloning kit (Invitrogen, Cergy Pontoise, France) and following the manufacturer's instructions. Double-stranded DNA sequencing was performed by the di-deoxy-chain termination method using a T3-T7 sequencing kit on a CEQ 2000 XL DNA sequencer (Beckman, Fullerton, CA, USA). Forward and reverse sequences were assembled in Sequencher 4.2 (Genecodes, Ann Arbor, MI, USA) and aligned using multalin (Corpet 1988). The ITS sequences obtained were deposited in the GenBank database (Table 1). Species-specific primers were then manually designed following inter- and intraspecific alignment and comparison of the ITS sequences with Multalin (Table 2).

\subsection{Construction of a PCR Internal Amplification Control (IAC)}

A heterologous DNA template with $5^{\prime}$ and $3^{\prime}$ ending sequences identical to the primer pair ITS-MMD-F and ITS-MMD-R was constructed according to the protocol described by Langrell (2002). Briefly, DNA extracted from leaves of Alnus glutinosa was subjected to random amplified polymorphic DNA (RAPD) with a low annealing temperature (36 ${ }^{\circ} \mathrm{C}$ ). A typical RAPD pattern was revealed by electrophoresis on a $1 \%$ agarose gel, and a ca. 1000-bp fragment was arbitrarily chosen as IAC for ITS-MMD-F/ITS-MMD-R-specific PCR. The entire RAPD product was cloned with the pCR ${ }^{\circledR} 4-\mathrm{TOPO}^{\circledR}-\mathrm{TA}$ cloning kit - following the manufacturer's instructions. The bacterial clone whose plasmid contained the selected fragment was screened by PCR with specific primers ITS-MMD-F/ITS-MMD-R according to the expected PCR product size. To determine the threshold of PCR sensibility and detection of the IAC, serial dilutions of bacterial suspensions containing the IAC were mixed with a $10 \mathrm{ng}-0.05 \mathrm{pg} \mu^{-1}$ range of $M m d$ DNA and tested by PCR with ITS-MMD-F/ITS-MMD-R primers. Ready-to-use IAC templates were stored as a suspension of transformed bacteria in ultrapure water at $-80^{\circ} \mathrm{C}$ until used for PCR.

\subsection{PCR amplification conditions using species-specific primers}

PCR assays were carried out as described above, except that $2 \mu \mathrm{l}$ of IAC was added to the PCR mix when ITS-MMD-F/ ITS-MMD-R primers were used. A PCR-negative control (no template DNA present in PCR) was included in all experiments.

Table 2. Sequence and specificity of the three Melampsora primer pairs developed in this study

\begin{tabular}{|c|c|c|c|}
\hline Primer pair & Sequence $\left(5^{\prime}-3^{\prime}\right)$ & Amplicon size & Specificity \\
\hline ITS-MLP-F & GAGCGCACTTTAATGTGACTC & $572 \mathrm{bp}$ & M. larici-populina \\
\hline ITS-MLP-R & ACTTAATTAAGTTGATAGGG & & \\
\hline ITS-MAP-F & СССАТТАССАССССАСССАА & $544 \mathrm{bp}$ & M. allii-populina \\
\hline ITS-MAP-R & TCTAAAGGTTAAATAAATAGG & & \\
\hline ITS-MMD-F & GAGTTGCTTAAATGCGATTC & $575 \mathrm{bp}$ & M. medusae \\
\hline ITS-MMD-R & CTAAAGGTAAATTCAATGGG & & $\begin{array}{l}\text { M. larici-tremulae } \\
\text { M. pinitorqua }\end{array}$ \\
\hline
\end{tabular}


Alternatively, single aecia or uredinia were simply ground for 10 min with ten 2-mm glass beads and $100 \mu \mathrm{l}$ of TE buffer in a 1.5-ml Eppendorf tube. In addition, samples of telia were ground with a pestle for 1 min in $100 \mu$ l of TE buffer. Two microlitres of both supernatants were diluted 10 -fold and then used as a template for PCR. All PCR were performed as described above, except that the annealing temperature was $50^{\circ} \mathrm{C}$. PCR products were separated by a 1 -h electrophoresis in $1 \%$ agarose gels in TBE buffer at $4 \mathrm{~V} \mathrm{~cm}^{-1}$ and visualized by U.V. exposition following ethidium bromide staining. The fragment sizes were estimated by comparison with a 100-bp DNA ladder (Invitrogen). Images were recorded with a GelDoc 2000 system (Biorad, Marnes-la-Coquette, France).

The sensitivity of the $M m d$-specific primers was assessed by testing serial dilutions ranging from $10 \mathrm{ng}^{-1} \mathrm{l}^{-1}$ to $0.05 \mathrm{pg} \mathrm{ll}^{-1}$ of Mmd genomic DNA (isolate 88MM1). DNA concentration of the initial solution was measured by Hoechst fluorometry.

\subsection{Survey procedures}

Since 1993, the French plant protection service has been carrying out annual inspections in commercial nurseries producing poplar saplings or cuttings to survey the quarantine pathogen $\mathrm{Mmd}$. Individual samples were made of 12 uredinia per cultivar and were sent for analysis to the Plant Health Laboratory (Anses, French Agency for Food, Environmental and Occupational Health \& Safety, Malzéville, France). From 1993 to 2002, the diagnostic protocol was based on the observation of morphological features using a light microscope (Pinon 1973; Vialle et al. 2011). From 2002, Anses started to use the PCRbased detection developed in this study. Briefly, 2-10 mg of uredinia was scraped from infected poplar leaves with a spatula in late summer and transferred into a sterile microcentrifuge tube to be sent to the laboratory for analysis. Each year, from 2002 to $2011,310,95,168,155,120,103,82,77,61$ and 64 rust samples were collected respectively and then analysed.

\section{Results}

\subsection{Primer specificity}

The specificity of each primer pair was assessed by PCR with DNA from 109 different isolates belonging to 9 distinct Melampsora species listed in Table 1, and with samples of poplar and larch DNA. The primer pair ITS-MLP-F/ITS-MLP-R amplified a single 572-bp DNA fragment from all the Mlp isolates (Fig. 1). In addition, PCR using ITS-MAP-F/ITS-MAP-R primers exclusively amplified a 544-bp DNA fragment from all the Map isolates (Fig. 1). No cross-reaction was reported for
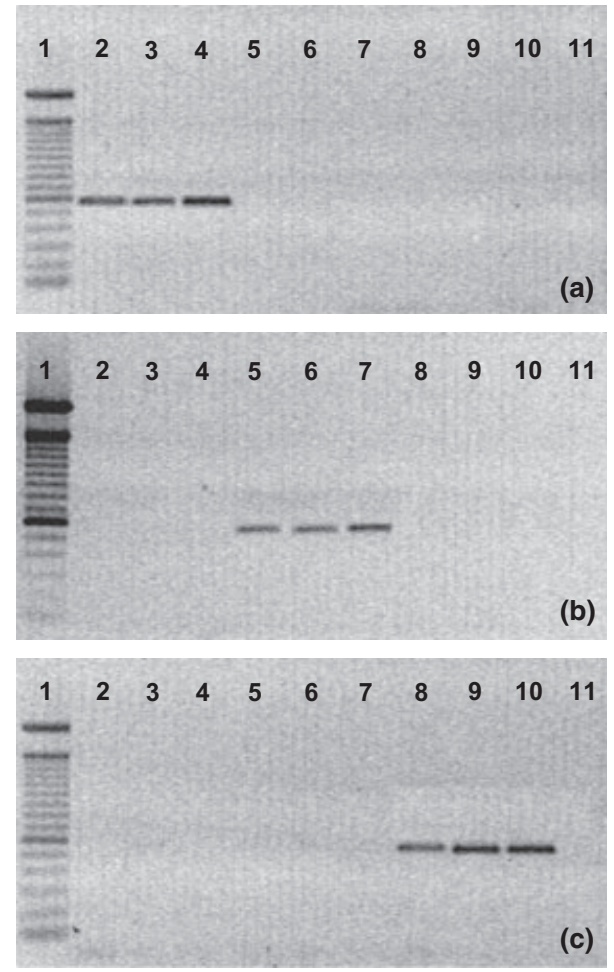

Fig. 1. PCR products from pure DNA of Melampsora sp. $\left(0.1-1 \mathrm{ng}^{-1} \mathrm{l}^{-1}\right)$ obtained with the primer pairs ITS-MLP-F/ITS-MLP-R (a), ITSMAP-F/ITS-MAP-R (b) and ITS-MMD-F/ITS-MMD-R (c). Lane1: 100-bp DNA ladder. Lanes 2-4: Mlp 97EA2, 97CF1 and 95XF6. Lanes 5-7: Map 96M24-2, 97L2 and 97L5. Lanes 8-10: Mmd 88MM2, 97CN1 and 97CN2. Lane 11: negative control with sterile ultrapure water. 
both primer pairs. PCR using the primer pair ITS-MMD-F/ITS-MMD-R produced a 575-bp DNA fragment from all the Mmd isolates (Fig. 1). However, cross-reactions were observed with M. larici-tremulae and M. pinitorqua isolates (Table 1 and 2). Last, no amplicon was obtained from poplar or larch DNA extracts with any of the species-specific primer pairs.

\subsection{PCR sensitivity}

The quantity of Mlp and Mmd urediniospores per milligram of fresh uredial material was estimated to be approximately 400000 and 320 000, respectively. In addition, the DNA amount in single urediniospores measured by Hoechst fluorometry was estimated to be $0.8 \mathrm{pg}$ for both species.

The detection threshold for the Mmd-specific PCR was firstly assessed by testing serial dilutions of Mmd DNA mixed with

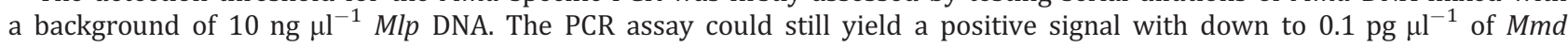
DNA (Fig. 2). As the elution volume was to $50 \mu \mathrm{l}$, this threshold detection would correspond to a starting quantity of six spores of $\mathrm{Mmd}$.

The detection level of the $M m d$-specific primers was also assessed by testing serial dilutions of $M m d$ urediniospores into Mlp urediniospores. The percentage of $M m d$ urediniospores in the two-first serial dilutions was estimated by counting to 8.64\% (63 of 729 spores) and $0.87 \%$ (4 of 461 spores), respectively. The results confirmed the expected number, that is, 8.16 and $0.82 \% \mathrm{Mmd}$ urediniospores, which means that dilutions were successfully performed. Therefore, the quantity of Mmd urediniospores in the six 2-mg mixture was estimated to be $67000,6700,670,67,6.7$ and 3.3 , respectively, into approximately $800000 \mathrm{Mlp}$ urediniospores. A positive PCR signal could be obtained with the DNA extract from the mixture containing an estimated number of 6.7 Mmd urediniospores (Fig. 3).

One hundred copies of bacteria containing the cloned IAC in each PCR tube proved to be adequate to allow the amplification of both targets in the presence of a wide range of $M m d$ DNA concentrations and therefore to check the absence of inhibitors in the PCR mix. However, no amplification of the IAC was obtained when a large amount of target Mmd DNA was added as a template in the PCR tube, that is, from 10 to $0.1 \mathrm{ng} \mu \mathrm{l}^{-1}$. Nevertheless, as the target Mmd DNA could be amplified, the absence of the IAC amplification product only meant that the large amount of target DNA prevented the amplification of the IAC by PCR competition and that no inhibitory compound was present. In the case where only the IAC band was produced, while no Mmd target was amplified, it was assumed that the DNA extract did not contain a detectable amount of Mmd DNA.

In addition, PCR tests with Mlp-specific primer pairs were successfully carried out on total DNA extracted from artificially inoculated or naturally infected poplar leaves or larch needle samples (data not shown).

\subsection{Detection by direct PCR without extraction}

PCR detection without prior DNA extraction was only tested with Mlp-specific primers. A single and clear band of approximately $570 \mathrm{bp}$ was detected from all the samples of infected leaves or infected needles tested (4 and 15 samples, respectively). On the other hand, PCR test carried out from ground samples of Mlp telia were less successful with only $40 \%$ of samples yielding a positive signal (three of eight samples).

\subsection{Inspections in commercial nurseries}

In 2002 and 2003, 405 rust samples collected in 310 and 29 nurseries, respectively, were analysed using both morphological and PCR methods. Results of both methods were similar in terms of relative frequency of Mlp vs. Map and their geographical distribution. Regardless of the year, Mlp and Map were detected in approximately 95 and $20 \%$ of the samples, respectively. Both species were found together in $11 \%$ of individual samples. As expected, Mlp was widespread in France, whereas M. allii-populina was more frequent in southern and western France. Mmd, meanwhile, was never detected. Similarly, resorting solely on the molecular detection tool, no Mmd was found in the 830 rust samples analysed between 2004 and 2011.

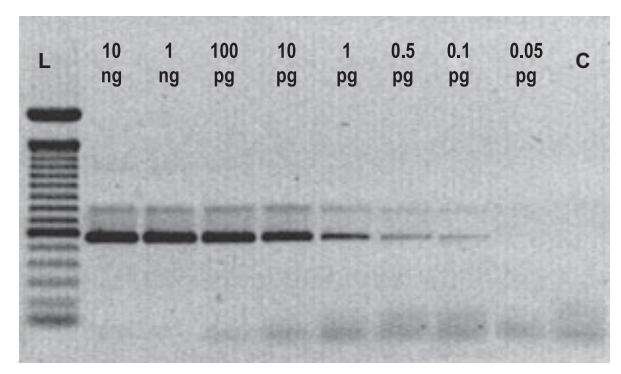

Fig. 2. PCR products obtained with the primer pairs ITS-MMD-F/ITS-MMD-R. The $M m d$ DNA template concentrations $\left(\mu \mathrm{l}^{-1}\right)$ added in PCR mixes are indicated above the lanes. L: 100-bp DNA ladder. C: negative control with sterile ultrapure water. 


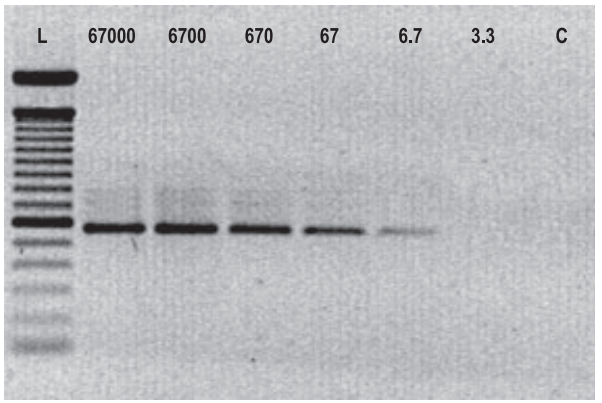

Fig. 3. PCR products obtained with the primer pairs ITS-MMD-F/ITS-MMD-R from a 2-mg mixture of urediniospores. The measured or estimated number of $M m d$ urediniospores in each mixture containing approximately 800000 urediniospores of Mlp is indicated above the lanes. L: 100-bp DNA ladder. C: negative control with sterile ultrapure water.

\section{Discussion}

The identification of European Melampsora species pathogenic on cultivated poplars can be achieved by microscopic observation of urediniospores and paraphyses (Pinon 1973; Vialle et al. 2011). This method can be easily implemented but is not suitable for routine analysis of a large number of samples because it is too time-consuming. In addition, morphological identification to the species level is not possible when only aecia or telia are available. The main goal of this study was the development of a rapid and reliable molecular method based on species-specific polymorphisms observed in the ITS rDNA region for identifying $M l p, M a p$ and $M m d$.

The primer pairs ITS-MLP-F/ITS-MLP-R yielded a unique 572-bp amplicon with DNA from Mlp. No cross-reaction was observed with DNA from the others species. Finally, these primers could be successfully used in PCR with DNA directly extracted from infected plant tissues, such as poplar leaves or larch needles, and regardless of the spore stage of the fungus as aeciospores, urediniospores or teliospores.

The primer pairs ITS-MAP-F/ITS-MAP-R designed in this study amplified a unique DNA fragment of 544 bp with DNA from Map. To our knowledge, this primer pair is the first molecular tool designed for the specific identification of Map.

The $M m d$-specific primers designed in this study produced a fragment of $575 \mathrm{bp}$ with DNA from all the isolates of $M m d$. No cross-reactions were observed except with M. larici-tremulae and M. pinitorqua DNA. However, as both species are only pathogenic on poplars belonging to the section Populus that are not used in commercial poplar cultivation, the primer pair ITS-MMD-F/ITS-MMD-R thus remains useful and specific for the detection of Mmd on cultivated poplars, that is, euramerican and interamerican hybrids. In addition, the sensitivity and selectivity of this new species-specific PCR test proved that it is fit for routine analysis. Indeed, detection of $\mathrm{Mmd}$ was not impeded by the presence of a background of DNA from nontarget species such as Mlp, which is the most widespread species in Europe. Moreover, the detection threshold was proved to be very low as the PCR test using Mmd primer pair was able to detect down to 6-7 target urediniospores among 800000 urediniospores of Mlp, that is, a ratio of $1: 100000$. Detection level is therefore reduced by 10000 -fold compared with the morphological method. Thus, the primer pair ITS-MMD-F/ITS-MMD-R could theoretically be able to detect a single Mmd uredinium among 100 leaves highly infected by Mlp collected on cultivated poplars. Lastly, the addition of an IAC in the PCR mix proved to be successful for detecting false negative results due to inhibitors.

The use of our molecular tools proved to be reliable and less time-consuming than the morphological method for surveying $M m d$ in commercial nurseries. They are now used as official methods for M. medusae f. sp. deltoidae detection in official quarantine laboratories. Despite the improved sensitivity of the PCR assay over the morphological method, Mmd was never detected from 2002 to 2011 in 1235 rust samples, confirming that this species is now absent - or present at undetectable level - on cultivated poplars in France. The situation is probably similar on wild poplars. In 2011, a survey carried out by the French forest health survey service (Département Santé des Forêts, DSF) throughout France did not allow to detect Mmd on leaves of P. nigra (Pascal Frey, unpublished data).

Very few single-nucleotide polymorphisms were observed in the ITS region between Mmd, M. larici-tremulae and M. pinitorqua, which means that this region is not the most appropriate target to specifically identify these species. This is consistent with a recent phylogeny study, showing that these three species that have a coniferous aecial host belong to the same clade (Vialle et al. 2012). In contrast, M. rostrupii, M. magnusiana and M. aecidioides that have an angiosperm aecial host belong to another clade. Further studies are needed to explore other regions of DNA, as single-copy genes, for discriminating Mmd, M. larici-tremulae and M. pinitorqua (Ioos et al. 2006; Aguileta et al. 2008; Feau et al. 2009).

In conclusion, highly sensitive, reliable, easy-to-use and rapid PCR-based methods have been developed for Melampsora species attacking cultivating poplars belonging to sections Aigeiros and Tacamahaca. These methods can be used on infected poplar and larch tissues and on mixtures of urediniospores collected on poplar leaves. However, Mmd-specific primers must be used with care as these primers cross-react with DNA from two Melampsora species pathogenic on section Populus. Thus, checking the poplar species on which rust samples are collected is necessary before using our PCR assays. Due to its very high sensitivity, Mmd-specific primers were applied as the official method for detecting the quarantine parasite Mmd on infected leaves in nurseries producing poplar cultivars for trade. The fact that this pathogen was never detected in France since 2002 has to be taken into account for the status of M. medusae f. sp. deltoidae as an A2 quarantine pest for EPPO. 


\section{Acknowledgements}

We are grateful for Philippe Loevenbruck from Anses for providing data on the official survey of M. medusae f. sp. deltoidae in France and Melinda Gatineau for her technical help. We thank all the colleagues listed in Table 1 for providing samples used in this study.

\section{References}

AFOCEL (eds.) 2009: Memento FCBA 2008-2009. Paris: AFOCEL, pp. 33.

Aguileta, G.; Marthey, S.; Chiapello, H.; Lebrun, M. H.; Rodolphe, F.; Fournier, E.; Gendrault-Jacquemard, A.; Giraud, T., 2008: Assessing the performance of single-copy genes for recovering robust phylogenies. Syst. Biol. 57, 613-627.

Bourassa, M.; Bernier, L.; Hamelin, R. C., 2005: Direct genotyping of the poplar leaf rust fungus, Melampsora medusae f. sp. deltoidae, using codominant PCR-SSCP markers. For. Pathol. 35, 245-261.

Bourassa, M.; Bernier, L.; Hamelin, R. C., 2007: Genetic diversity in poplar leaf rust (Melampsora medusae f. sp deltoidae) in the zones of host sympatry and allopatry. Phytopathology 97, 603-610.

Boyle, B.; Hamelin, R. C.; Seguin, A., 2005: In vivo monitoring of obligate biotrophic pathogen growth by kinetic PCR. Appl. Environ. Microbiol. 71, 1546-1552.

Charcosset, J. Y.; Gardes, M., 1999: Infraspecific genetic diversity and substrate preference in the aquatic hyphomycete Tetrachaetum elegans. Mycol. Res. 103, 736-742.

Chung, W. H.; Chung, W. C.; Ting, P. F.; Huang, H. C.; Huang, J. W., 2008: Molecular identification of Uromyces appendiculatus and Uromyces vignae from Taiwan with PCR-based method. Plant. Pathol. 17, 297-305.

Corpet, F., 1988: Multiple sequence alignment with hierarchical clustering. Nucleic Acids Res. 16, 10881-10890.

Desprez-Loustau, M. L.; Robin, C.; Reynaud, G.; Déqué, M.; Badeau, V.; Piou, D.; Husson, C.; Marçais, B., 2007: Simulating the effects of a climate-change scenario on the geographical range and activity of forest-pathogenic fungi. Can. J. Plant Pathol. 29, 101-120.

Eckenwalder, J. E., 1996: Systematics and evolution of Populus. In: Biology of Populus and its implications for management and conservation. Ed. by Stettler, R. F.; Bradshaw Jr, H. D.; Heilman, P. E.; Hinckley, T. M. Ottawa: NRC Research Press, pp. 7-32.

Feau, N.; Vialle, A.; Allaire, M.; Tanguay, P.; Joly, D. L.; Frey, P.; Calland, B. E.; Hamelin, R. C., 2009: Fungal pathogen (mis-) identifications: a case study with DNA barcodes on Melampsora rusts of aspen and white poplar. Mycol. Res. 113, 713-724.

Frey, P.; Gérard, P.; Feau, N.; Husson, C.; Pinon, J., 2005: Variability and population biology of Melampsora rusts on poplars. In: Rust diseases of Willow and Poplar. Ed. by Pei, M. H.; McCracken, A. R.. Wallingford: CAB International, pp. 63-72.

Gastine, F.; Berthelot, A.; Bouvet, A., 2003: La protection phytosanitaire du cultivar 'Beaupré' est-elle efficace ? Fiche Informations - Forêt AFOCEL 667, pp. 4

Gérard, P.; Husson, C.; Pinon, J.; Frey, P., 2006: Comparison of genetic and virulence diversity of Melampsora larici-populina populations on wild and cultivated poplar and influence of the alternate host. Phytopathology 96, 1027-1036.

Hacquard, S.; Veneault-Fourrey, C.; Delaruelle, C.; Frey, P.; Martin, F.; Duplessis, S., 2011: Validation of Melampsora larici-populina reference genes for in planta RT-quantitative PCR expression profiling during time-course infection of poplar leaves. Physiol. Mol. Plant P. 75, $106-112$.

Henrion, B.; Chevalier, G.; Martin, F., 1994: Typing truffle species by PCR amplification of the ribosomal DNA spacers. Mycol. Res. 98, 3743.

Ioos, R.; Laugustin, L.; Schenck, N.; Rose, S.; Husson, C.; Frey, P., 2006: Usefulness of single copy genes containing introns in Phytophthora for the development of detection tools for the regulated species P. ramorum and P. fragariae. Eur. J. Plant Pathol. 116, 171-176.

Langrell, S. R. H., 2002: Molecular detection of Neonectria galligena (Syn. Nectria galligena). Mycol. Res. 106, 280-292.

Miot, S.; Frey, P.; Pinon, J., 1999: Varietal mixture of poplar clones: effects on infection by Melampsora larici-populina and on plant growth. Eur. J. For. Pathol. 29, 411-423.

Newcombe, G.; Chastagner, G. A.; Schuette, W.; Stanton, B. J., 1994: Mortality among hybrid poplar clones in a stool bed following leaf rust caused by Melampsora medusae f. sp. deltoidae. Can. J. For. Res. 24, 1984-1987.

OEPP/EPPO 1982: Data sheets on quarantine organisms no. 33, Melampsora medusae. Bull. OEPP/EPPO 12, pp. 6.

Paris, P.; Mareschi, L.; Sabatti, M.; Pisanelli, A.; Ecosse, A.; Nardin, F.; Scarascia-Mugnozza, G., 2011: Comparing hybrid Populus clones for SRF across northern Italy after two biennial rotations: survival, growth and yield. Biomass Bionergy 35, 1524-1532.

Pedley, K. F., 2009: PCR-Based assays for the detection of Puccinia horiana on Chrysanthemums. Plant Dis. 93, $1252-1258$.

Pei, M. H.; Whelan, M. J.; Halford, N. G.; Royle, D. J., 1997: Distinction between stem- and leaf-infecting forms of Melampsora rust on Salix viminalis using RAPD markers. Mycol. Res. 101, 7-10.

Pinon, J., 1973: Les rouilles du Peuplier en France: systématique et répartition du stade urédien. Eur. J. For. Pathol. 3, 221-228.

Pinon, J., 1986: Situation of Melampsora medusae in Europe. Bull. OEPP 16, 547-551.

Pinon, J., 1991: Eléments de répartition des rouilles des peupliers cultivés en France. Comptes-Rendus de l'Académie d'Agriculture de France 77, 109-115.

Pinon, J.; Frey, P., 2005: Interactions between poplar clones and Melampsora populations and their implications for breeding for durable resistance. In: Rust diseases of Willow and Poplar. Ed. by Pei, M. H.; McCracken, A. R. Wallingford: CAB International, pp. 139-154.

Pinon, J.; Frey, P.; Husson, C., 2006: Wettability of poplar leaves influences dew formation and infection by Melampsora larici-populina. Plant Dis. 90, 177-184.

Pinon, J.; Berthelot, A.; Fabre, B., 2011: Comportement des cultivars de Peuplier envers la rouille. Rev. For. Fr. 63, 333-346.

$\mathrm{Pu}$, Y. Q.; Kosa, M.; Kalluri, U. C.; Tuskan, G. A.; Ragauskas, A. J., 2011: Challenges of the utilization of wood polymers: how can they be overcome? Appl. Microbiol. Biotechnol. 91, 1525-1536.

Royle, D. J.; Ostry, M. E., 1995: Disease and pest control in the bioenergy crops poplar and willow. Biomass Bioenergy 9, 69-79.

Schoch, C. L.; Seifert, K. A.; Huhndorf, S.; Robert, V.; Spouge, J. L.; Levesque, C. A.; Chen, W.; Fungal Barcoding Consortium, 2012: Nuclear ribosomal internal transcribed spacer (ITS) region as a universal DNA barcode marker for Fungi. Proc. Nat. Acad. Sci. 109, $6241-6246$.

Swana, J.; Yang, Y.; Behnam, M.; Thompson, R., 2011: An analysis of net energy production and feedstock availability for biobutanol and bioethanol. Bioresource Technol. 102, 2112-2117.

Vande Walle, I.; Van Camp, N.; Van de Casteele, L.; Verheyen, K.; Lemeur, R., 2007: Short-rotation forestry of birch, maple, poplar and willow in Flanders (Belgium) I - Biomass production after 4 years of tree growth. Biomass Bioenergy 31, 267-275.

Vialle, A.; Frey, P.; Hambleton, S.; Bernier, L.; Hamelin, R. C., 2011: Poplar rust systematics and refinement of Melampsora species delineation. Fungal Divers. 50, 227-248. 
Vialle, A.; Feau, N.; Frey, P.; Bernier, L.; Hamelin, R. C., 2012: Phylogenetic species recognition reveals host-specific lineages among poplar rust fungi. Mol. Phylogenet. Evol. (in press).

Walker, J.; Hartigan, D.; Bertus, A. L., 1974: Poplar rusts in Australia with comments on potential conifer rusts. Eur. J. For. Pathol. 4, 100118.

White, T. J.; Bruns, T.; Lee, S.; Taylor, J., 1990: Amplification and direct sequencing of fungal ribosomal RNA genes for phylogenetics. In: PCR Protocols: A Guide to Method and Applications. Ed. by Innis, M. A.; Gelfand, D. H.; Sninsky, J. J.; White, T. J.. New-York: Academic Press, pp. 315-322.

Widin, K. D.; Schipper Jr, A. L., 1981: Effect of Melampsora medusae leaf rust infection on yield of hybrid poplars in the north-central United States. Eur. J. For. Pathol. 11, 438-448.

Wilkinson, A. G.; Spiers, A. G., 1976: Introduction of poplar rusts Melampsora larici-populina and Melampsora medusae to New-Zealand and their subsequent distribution. N. Z. J. Sci. 19, 195-198. 